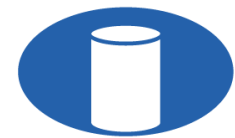

IBRACON Structures and Materials Journal

Revista IBRACON de Estruturas e Materiais

IBRACON

ISSN 1983-4195

ismj.org

ORIGINAL ARTICLE

\title{
Combined evaluation of oscillatory rheometry and isothermal calorimetry for the monitoring of hardening stage of Portland cement compositions blended with bauxite residue from Bayer process generated in different sites in Brazil
}

\section{Avaliação combinada de reometria oscilatória e calorimetria isotérmica para o monitoramento do estágio de endurecimento de composições de cimento Portland misturadas com resíduos de bauxita do processo Bayer coletados em diferentes locais no Brasil}

\author{
Roberto Cesar de Oliveira Romano ${ }^{\mathrm{a}}$ (it) \\ José Augusto Ferreira Sales de Mesquita ${ }^{\mathrm{a}}$ (i) \\ Heitor Montefusco Bernardo ${ }^{a}$ (ib \\ Danilo Aguiar Niza ${ }^{a}$ (D) \\ Marcel Hark Maciel $^{\mathrm{a}}$ (D) \\ Maria Alba Cincotto ${ }^{\mathrm{a}}$ (i) \\ Rafael Guiliano Pileggi ${ }^{\mathrm{a}}$
}

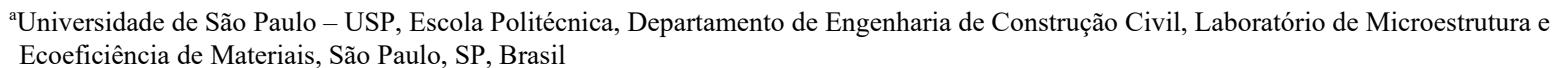

Received 08 April 2020

Accepted 10 July 2020

\begin{abstract}
Bauxite residue (BR), a by-product of alumina and aluminum production, consists of high aluminum, silica, and iron content, and sodium from the bauxite ore digestion during the Bayer process. This waste is still being disposal into the lakes of mud, causing some environmental problems. So, the search for its application has gained interest. Studies reported in literature point out that one of the most promising applications is in association with Portland cement, which can also help to reduce the environmental impact caused by the $\mathrm{CO} 2$-emissions in its production. In this work, a combined evaluation of oscillatory rheometry and isothermal calorimetry was performed for the monitoring of the hardening stage of Portland cement (PC) compositions blended with BR generated in different sites in Brazil. The time-sweep test was applied to obtain the consistency gain of suspensions over-time, allowing us to understand the physical parameters of consolidation, while the changes in the hydration reaction showed considerable differences in the chemical contribution. As a conclusion, it was clear the impact of each BR, mainly due to the aspects related to soluble aluminates, silicates, and sodium, which in association with the soluble ions from PC, affected the chemical reaction and agglomeration/flocculation forces of particles.
\end{abstract}

Keywords: rheological properties, reuse of bauxite residue, Portland cement, chemical reactions.

Resumo: O resíduo de bauxita (BR), um subproduto da produção de alumina e alumínio, apresenta alto teor de alumínio, silício e ferro proveniente da bauxita, e sódio da digestão do minério durante o processo Bayer. Esse resíduo ainda está sendo descartado nos lagos de lama, causando alguns problemas ambientais. Assim, a busca por uma aplicação em larga escala tem ganhado cada vez mais atenção. Estudos relatados na literatura apontam que uma das aplicações mais promissoras está associada ao cimento Portland, o que também pode ajudar a reduzir o impacto ambiental causado pelas emissões de $\mathrm{CO}_{2}$ durante a produção do ligante hidráulico. Neste trabalho, uma avaliação combinada de reometria oscilatória e calorimetria isotérmica foi realizada para o monitoramento do estágio de endurecimento de composições de cimento Portland (PC) misturadas com BR

Corresponding author: Roberto Cesar de Oliveira Romano. E-mail: rcorjau@gmail.com

Financial support: Alcoa Foundation, Companhia Brasileira do Alumínio - CBA, FAPESP, CNPq.

Conflict of interest: Nothing to declare.

This is an Open Access article distributed under the terms of the Creative Commons Attribution License, which permits unrestricted use, distribution, and reproduction in any medium, provided the original work is properly cited. 
geradas em diferentes locais no Brasil. O ensaio de varredura no tempo foi aplicado para monitorar o ganho de consistência das suspensões ao longo do tempo, permitindo avaliar os parâmetros físicos da consolidação, enquanto as mudanças na reação de hidratação mostraram as diferenças consideráveis realacionadas com a contribuição química. Como conclusão, ficou claro o impacto de cada BR, principalmente devido aos aspectos relacionados aos aluminatos, silicatos e sódio solúveis, que em associação com os íons solúveis do PC, afetaram a reação química e as forças de aglomeração/floculação das partículas.

Palavras-chave: propridades reológicas, resuso de resíduo de bauxita, cimento Portland, reação química.

How to cite: R. C. O. Romano et al., "Combined evaluation of oscillatory rheometry and isothermal calorimetry for the monitoring of hardening stage of Portland cement compositions blended with bauxite residue from Bayer process generated in different sites in Brazil" Rev. IBRACON Estrut. Mater., vol. 14, no. 2, e14211, 2021, https://doi.org/10.1590/S1983-41952021000200011

\section{INTRODUCTION}

Bauxite residue (BR), commonly known worldwide as red mud, is a highly alkaline material generated from the production of alumina in the Bayer process, in which bauxite is dissolved in caustic soda. A common estimative is that 1 ton of $\mathrm{BR}$ is generated for each 1 ton of alumina produced (i.e. the amount of aluminum oxide trihydrate produced and expressed as $100 \%$, nominal aluminum oxide $\left(\mathrm{Al}_{2} \mathrm{O}_{3}\right)$ equivalent, independently of further processing), but some statistics illustrate that this proportion can variate depended on the ore richness, being between 0.8 and 1.3 [1].

Independently of that, the global BR inventory reached around 4.6 billion tons in 2018, with a worldwide production rate of almost 200 million tons per year. Brazil has the third-largest bauxite deposit on the planet, being the fourthlargest producer of alumina and is the fifth country in the exportation of aluminum or alloys. Accompanying the advancement of this industry, the generation of waste has grown more and more, and the search for applications for BR is an alternative that has gained strength year-on-year [2]-[8].

So, there has been an important amount of work done in recycling and reusing this kind of material, but despite the development of some minor applications, and the fact that no large-scale application has yet been achieved the residue still has to be discarded in lakes of mud [5], [9], [10].

Romano et al. [11], [12] applied different methods for monitoring the chemical reaction of Portland cement in association with using bauxite residue, detecting, beyond the ordinary hydrated products of pure Portland cement, the formation of sodium silicoaluminate hydrate (NASH), and calcium aluminate. Fujii et al. [13] evaluated the impact of using superplasticizers in the consolidation of Portland cement suspensions blended with bauxite residue, concluding that the stage of hardening was considerably affected by the kind and content of admixture. Dodoo-Arhin et al. [14] evaluated the impact of using BR from the region of Awaso in Ghana, calcined at $800{ }^{\circ} \mathrm{C}$, in the properties of pavements produced with microconcrete of Portland cement concluding that up to $5 \%$ of substitution of PC there was not any loss in the mechanical strength or water absorption. Krivenko et al. [15] developed some alkali-activated concretes using a large amount of bauxite residue, pointing out for the formation of C-S-H, klinoferrosilite $\left(\mathrm{FaSiO}_{3}\right)$ and lawsonite, $\left(\mathrm{CaA}_{12}\left[\mathrm{Si}_{2} \mathrm{O}_{7}\right](\mathrm{OH})_{2} \cdot \mathrm{H}_{2} \mathrm{O}\right)$. The authors evaluated the mechanical strength, and leaching of heavy-metals and radiative elements, concluding that the components are following the standardized specifications for application in roads. Romano et al. [16] showed the impact of using bauxite residue in microconcrete of Portland cement and did a comparison with other kinds of ordinary supplementary cementitious materials, concluding that this practice is technically viable. Pontikes and Angelopoulos [17] presented a review of some applications of bauxite residue in association with Portland cement, providing a critical point of view of the research conducted in the last 40 years. In this paper, the authors pointed out that the main barrier for the transition from the laboratory scale to the industry is the economic aspect.

This is a fact, and even these days, the cost of disposal is between 4 and 12 dollars per ton, and this is part of the difficulty in the search for a viable solution for this huge residue generation [18].

However, for the construction of these deposits, it is necessary to manage large areas, affecting considerably the local fauna and flora [5], [10], [19], [20]. Additionally, there is always the possibility of an environmental catastrophe, such as that occurred in Hungary, October 2010, causing a state of emergency of 3 cities around the lake [11].

Evans [21] did another review, considering the storage and disposal of bauxite residue in the $19^{\text {th }}$ century, discussing the changes in the environmental aspects. Some successful remediation and rehabilitation trends in Jamaica have been described, as well as proposed uses for BR. The survey indicates the considerable number of patents and technically feasible proposals for the use of BR, but that only about 4 million tons are used productively. Therefore, the author discusses the main barriers and why they are not used on a large scale, even with proven technical feasibility. Besides, it is mentioned that the use in association with cement or cementitious components, the raw material for steelmaking, landfill closure, soil improvement, and road construction, are the most promising alternatives.

According to some authors, the high alkalinity is the critical factor restricting complete utilization of bauxite residues, whilst the application of alkaline regulation agents is costly and difficult to apply widely [1], [11], [17]. 
It was also observed that one of the biggest problems is that BR shows a considerable chemical, mineralogical and physical variation from site to site, and a suitable solution for one collected waste cannot be adequate for another one [8], [18]. For instance, monitoring did by Garcia [22] indicates that iron content in the residue can vary from 20 to $60 \%$, aluminum content from 10 to $58 \%$, silica from 3 to $65 \%$, and sodium from 0.4 to $15 \%$, impacting considerably on the mineralogical phases.

Additionally, the strongly alkaline nature of bauxite residue and its ions leaching potential ability, are other drawbacks that need to be considered for most valorization routes [7]. So, as the large variability of BR can make difficult to implement of a single solution, in this first step of the study of this material the main goal is to evaluate the impact of the kind and content of different bauxite residues on rheological properties and chemical reactions of cement, a stage that impacts considerably on the microstructural development of cementitious materials.

\section{MATERIALS AND EXPERIMENTAL PROGRAM}

The purest Brazilian Portland cement was the binder choose to develop this work. It is referred to as a CPV according to the Brazilian standard [23]. Bauxite residues studied are from three different sites described as NE-BR - São Luís - MA, SE-BR1 Poços de Caldas (MG), and SE-BR2 - Aluminio (SP), obtained from the Bayer process of aluminum production in plants from Northeast (NE) or Southeast (SE) regions. As the residues were received wet and in clods, it was necessary a prior preparation: drying at $105^{\circ} \mathrm{C}$ for 24 hours, grinding in a mill, and sieving with a 106-micron mesh sieve.

\section{Characterization}

X-ray fluorescence (FRX), in PANalytical equipment, model Minipal Cement, and X-ray diffraction (XRD) in a PANalytical X'PERT-MPD, were used to determine the chemical and mineralogical composition of each raw material, respectively, following the procedures reported by Romano et al. [12], and the thermal decomposition was quantified using a Netzsch thermobalance, model STA409EP [24].

The particle size distribution was measured on a laser granulometer, Helos (Sympatec) [25], the specific surface area was determined by $\mathrm{N} 2$ adsorption at $77 \mathrm{~K}$ in a Belsorp Max equipment [12], the real density was determined by gas He pycnometry in Quantachrome equipment, MVP 5DC, while the pozzolanic index was defined by applying the method described in the NBR 15895/10 - Pozzolanic materials - Modified Chapelle method. The images of scanning electron microscopy (SEM) were obtained using a Quanta 600FEG instrument.

\section{Preparation of the pastes}

Pastes were produced maintaining the water-to-solid ratio of 0.50 , using a composition with pure cement (i.e., for reference) and 9 more compositions with partial replacement, in weight, of 5, 10, and 20\% of cement by the bauxite residues. Table 1 illustrates the evaluated compositions, indicating the nomenclatures used for each one.

Table 1 Compositions evaluated in the study.

\begin{tabular}{ccccc}
\hline Nomenclature & Portland cement & NE-BR & SE-BR1 & SE-BR2 \\
\hline CPV & 100 & - & - & - \\
\hline 5NE-BR & 95 & 5 & - & - \\
\hline 10NE-BR & 90 & 10 & - & - \\
\hline 20NE-BR & 80 & 20 & 5 & - \\
\hline 5SE-BR1 & 95 & - & 10 & - \\
\hline 10SE-BR1 & 90 & - & 20 & - \\
\hline 20SE-BR1 & 80 & - & - & 5 \\
\hline 5SE-BR2 & 95 & - & - & 10 \\
\hline 10SE-BR2 & 90 & - & - & 20 \\
\hline 20SE-BR2 & 80 & - & & \\
\hline
\end{tabular}

$\mathrm{NE}$ - Brazilian northeast; SE - Brazilian southeast; BR - bauxite residue. The number described in the Nomenclature column indicates the percentage of Portland cement replacement by BR.

All dry components were blended and placed into a metal container. The water was added, and 30 seconds was allowed for the initial wetting of the particles. After that, mechanical dispersion was applied at a constant speed of 10,000 rpm for 90 seconds using a Cowles' impeller. 


\section{Isothermal calorimetry}

The heat released during the hydration reaction of Portland cement was monitored for 48 hours in an isothermal calorimeter, TAM Air model, TA Instruments, following the procedure described by Romano et al. [24]. The stages of hydration reaction were discussed according to reported in the same work.

\section{Oscillatory rheometry}

Tests were performed in a Mars 60, Haake rheometer, using a parallel-plate type geometry. Samples were prepared following the procedure described in Fujii et al. [9], and all tests were performed at a temperature of $23^{\circ} \mathrm{C}$. Time sweep test was the procedure choose for the monitoring of gain of consistency over time, performed maintaining the strain at $10^{-4}$, and frequency of $1 \mathrm{~Hz}$ for 6 hours.

The rheological evaluation is fundamental for the comprehension of the phenomena that can affect the stage of transportation, application, workability, and time stability. In this work, the changes promoted by BR addition were monitored using the time sweep test: the application of strain and frequency in the linear viscoelastic region (LVR) makes it possible to monitor the increase in the particle agglomeration forces without any external interference in the formed microstructure, i.e. without the microstructure breaking down. As a result, it was measured the gain on consistency over the time, represented by G', of each blended suspension.

\section{RESULTS AND DISCUSSIONS}

\section{Materials characterization}

Table 2 presents the chemical analysis of each material. The iron content in the waste NE-BR, $56 \%$, was higher than for the other residues, $29.5 \%$ and $37.1 \%$, respectively for SE-BR1 and SE-BR2. Due to this large amount found in the waste, some works are reported in literature trying to recover iron from the bauxite residue [26], [27], but the process is not yet economically viable, and the remaining waste (with a low amount of iron) is still discarded. Other works are purposed to understand the mechanisms of iron interaction with cementitious materials for predicting the service life and design of reinforced concrete structures [28].

The large amounts of aluminum and silica illustrate, respectively, the low efficiency of the Bayer process and the considerable amount of impurities in the bauxite ore. Kaußen and Friedrich [29], evaluated a way to recover Al from bauxite residue using dissolution in caustic soda at high pressure followed by thermal treatment, but even with an efficiency around $90 \%$, the contamination with silica is still a problem, due to the complete dissolution of aluminum silicates.

The loss of ignition comprises the humidity, $\mathrm{CO}_{2}$ from the decomposition of carbonates, and combined water from zeolites, goethite, and gibbsite dehydroxylation.

The ratio between aluminum, calcium, and silicon oxides obtained for these residues, illustrate that both are in accordance with the results presented by Romano et al. [12] in the ternary diagram of supplementary cementitious materials.

The SE-BR1 has higher alkalinity due to the higher amounts of $\mathrm{Na}_{2} \mathrm{O}$ and $\mathrm{K}_{2} \mathrm{O}$ content. This is an important characteristic to be observed because the alkalis content can limit the use of bauxite residue as a supplementary cementitious material.

The higher the amount of soluble ions, the higher the susceptibility to leaching if these elements do not participate in hydrated compounds formation.

As the hydration of Portland cement is governed by the dissolution/precipitation and by the equilibrium shifting, the soluble ions inserted in the blends replacing partially Portland cement by different kinds of bauxite residue directly affects the chemical reaction.

The soluble ions of each residue were quantified for this work mixing $10 \mathrm{~g}$ of residue in $100 \mathrm{ml}$ of deionized water. This suspension was mixed for 30 minutes and then kept at rest for more 30 minutes. After this time, the water was separated from the powder by filtration and used in the determinations. For the determination of soluble ions, it was applied the recommendations of ASTM C114-18: Standard Test Methods for Chemical Analysis of Hydraulic Cement, and the Brazilian standard NBR 13810/1997: Water - Determination of metals - Method determination of metals spectrometric method by flame absorption. 
Table 2 Chemical composition of Portland cement and bauxite residues.

\begin{tabular}{|c|c|c|c|c|}
\hline \multirow{2}{*}{ Determinations } & \multicolumn{4}{|c|}{$\%$ (dry basis) } \\
\hline & CPV & NE-BR & SE-BR1 & SE-BR2 \\
\hline Calcium oxide $(\mathrm{CaO})$ & 60.8 & 0.72 & 2.76 & 4.58 \\
\hline Silicon oxide (SiO2) & 19.2 & 10.0 & 16.6 & 12.8 \\
\hline Aluminum oxide (A12O3) & 4.94 & 11.5 & 18.7 & 16.5 \\
\hline Iron oxide $(\mathrm{Fe} 2 \mathrm{O} 3)$ & 2.97 & 56.6 & 29.5 & 37.1 \\
\hline Sulfur oxide (SO3) & 4.47 & 0.32 & 0.31 & 1.19 \\
\hline Magnesium oxide (MgO) & 0.67 & und & 0.07 & 0.09 \\
\hline Sodium oxide $(\mathrm{Na} 2 \mathrm{O})$ & 0.15 & 6.43 & 8.41 & 7.38 \\
\hline Potassium oxide (K2O) & 0.70 & 0.32 & 2.21 & 0.42 \\
\hline Alkaline Eq. $(\% \mathrm{~K} 2 \mathrm{O} \times 0.658+\% \mathrm{Na} 2 \mathrm{O})$ & 0.61 & 6.64 & 9.86 & 7.18 \\
\hline Titanium oxide $(\mathrm{TiO} 2)$ & 0.26 & 2.91 & 4.96 & 3.64 \\
\hline Phosphorus oxide (P2O5) & 0.27 & 0.06 & 0.50 & 0.55 \\
\hline Zirconium oxide ( $\mathrm{ZrO} 2)$ & - & 0.47 & 0.74 & 0.28 \\
\hline Cromium oxide (Cr2O3) & - & 0.09 & 0.03 & 0.09 \\
\hline Niobium oxide (Nb2O5) & - & 0.02 & 0.22 & 0.02 \\
\hline Other oxides & 1.70 & 0.06 & 1.29 & 0.24 \\
\hline Loss on ignition (LOI) & 3.87 & 10.5 & 13.7 & 15.4 \\
\hline
\end{tabular}

Results obtained are presented in Table 3, illustrating that the residues SE-BR2 and SE-BR1 presented a larger amount of soluble ions than NE-BR. This information is relevant because, as will be seeing later, the residues from SE Brazilian region influenced the chemical reaction more than NE.

Table 3 Soluble ions quantified mixing $10 \mathrm{~g}$ of residue in $100 \mathrm{ml}$ of deionized water. Results are presented in $\mathrm{mmol} / \mathrm{kg}$ of BR.

\begin{tabular}{cccc}
\hline Ions & NE-BR & SE-BR1 & SE-BR2 \\
\hline $\mathrm{Na}+$ & 89.8 & 109.0 & 123.3 \\
\hline $\mathrm{K}+$ & 0.88 & 1.76 & 0.88 \\
\hline $\mathrm{AlO} 2-$ & 7.94 & 2.27 & 3.40 \\
\hline
\end{tabular}

Figure 1 presents the XRD curves for bauxite residues and Table 4 presents the mineralogical composition of the three samples.

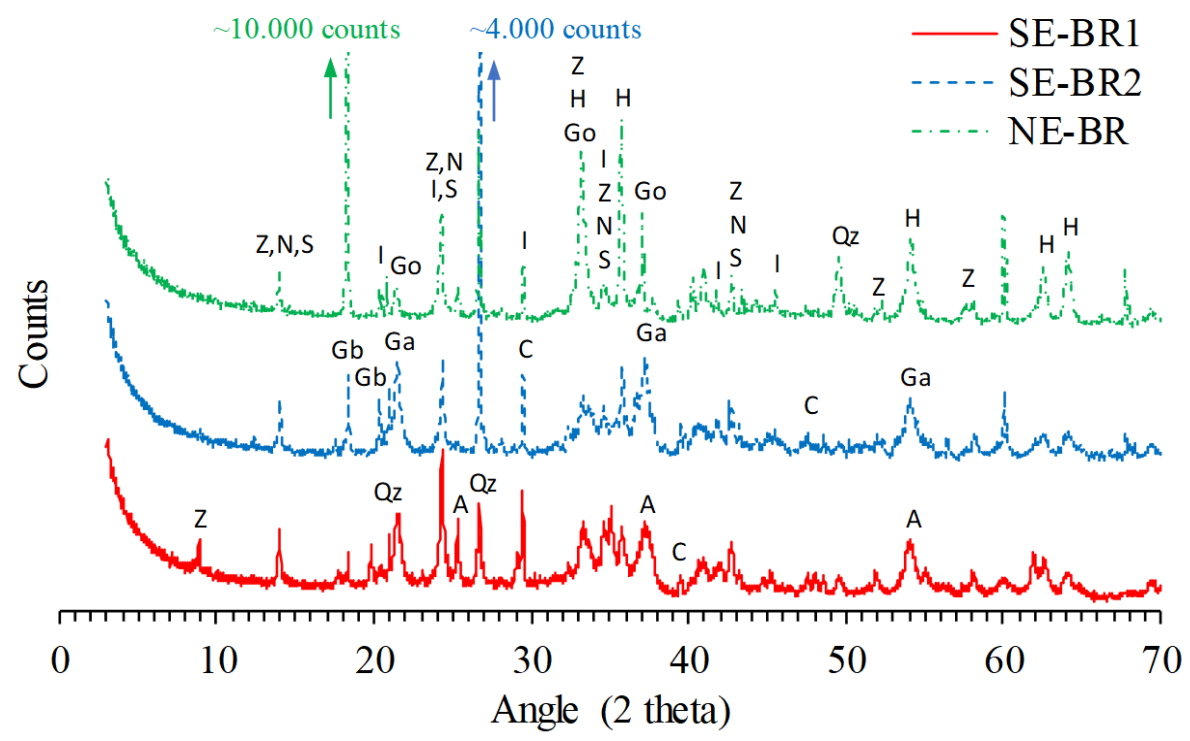

Figure 1. X-ray diffractograms of bauxite residues. 
Table 4. Mineralogical phase, molecular formula, and consulted the file number of the phases found in the bauxite residues.

\begin{tabular}{cccc}
\hline Mineralogical phase & Molecular formula & Consulted file & Main peaks $\left({ }^{\circ}\right)$ \\
\hline Zeolite $(\mathrm{Z})$ & $1.08 \mathrm{Na} 2 \mathrm{O} \cdot \mathrm{Al} 2 \mathrm{O} 3 \cdot 1.68 \mathrm{SiO} 2 \cdot 1.8 \mathrm{H} 2 \mathrm{O}$ & $00-031-1271$ & $24.2^{*}, 13.9,8.97$ \\
\hline Sodium aluminum silicate nitrate $(\mathrm{N})$ & $\mathrm{Na} 7.9(\mathrm{Al} 6 \mathrm{Si} 6 \mathrm{O} 24) \cdot(\mathrm{NO} 2) 0.9 \cdot(\mathrm{NO} 3) 1.2$ & $01-082-1080$ & $24.3^{*}, 14.0,34.6$ \\
\hline Illite $(\mathrm{I})$ & $\mathrm{K} 2 \mathrm{Al} 4 \mathrm{Si} 8 \mathrm{O} 24$ & $96-901-3720$ & $24.4^{*}, 29.1,35.0$ \\
\hline Sodalite $(\mathrm{S})$ & $\mathrm{Na} 8 \mathrm{Al6Si6O} 24 \mathrm{Cl} 2$ & $96-900-3327$ & $24.3^{*}, 13.9,34.7$ \\
\hline Hematite $(\mathrm{H})$ & $\mathrm{Fe} 2 \mathrm{O} 3$ & $00-013-0534$ & $33.3^{*}, 54.2,35.7$ \\
\hline Goethite $(\mathrm{Go})$ & $\mathrm{FeO}(\mathrm{OH})$ & $96-900-3080$ & $21.6^{*}, 37.2,33,7$ \\
\hline Gibbsite $(\mathrm{Gb})$ & $\mathrm{Al}(\mathrm{OH}) 3$ & $96-101-1082$ & $18.3^{*}, 20.3,20.6$ \\
\hline Quartz $(\mathrm{Qz})$ & $\mathrm{SiO} 2$ & $96-500-0036$ & $26.6^{*}, 50.1,20.9$ \\
\hline Calcite $(\mathrm{C})$ & $\mathrm{CaCO}$ & $01-072-1652$ & $29.5^{*}, 48.6,47.7$ \\
\hline Anatase $(\mathrm{A})$ & $\mathrm{TiO} 2$ & $96-900-8214$ & $25.3^{*}, 37.8,53.9$ \\
\hline
\end{tabular}

* $100 \%$ of the intensity

The three main peaks of each mineralogical phase are illustrated, being the gibbsite, goethite, and hematite the most important phases. Sodalite, due to the bauxite ore digestion with caustic soda, a zeolite, and a sodium aluminum silicate nitrate phases were also observed in all residues. The considerable amount of potassium quantified by X-ray fluorescence was detected as illite, mainly in the SE-BR1.

The CPV cement XRD diffractogram (not shown) indicated the main clinker phases, gypsum, and a small content of syngenite.

Figure 2 shows the DTG results, confirming that between 30 and $150^{\circ} \mathrm{C}$ there is the moisture evaporation; around $200^{\circ} \mathrm{C}$ there is a peak referred to the loss of zeolitic water; from 210 to $295^{\circ} \mathrm{C}$ the loss of water, related to the conversion of gibbsite in g-alumina; between 295 and $420^{\circ} \mathrm{C}$ the transformation of goethite to hematite; around $520^{\circ} \mathrm{C}$ there is an indication of diaspore decomposition, and from $550^{\circ} \mathrm{C}$ to $700^{\circ} \mathrm{C}$ related to calcite decomposition.

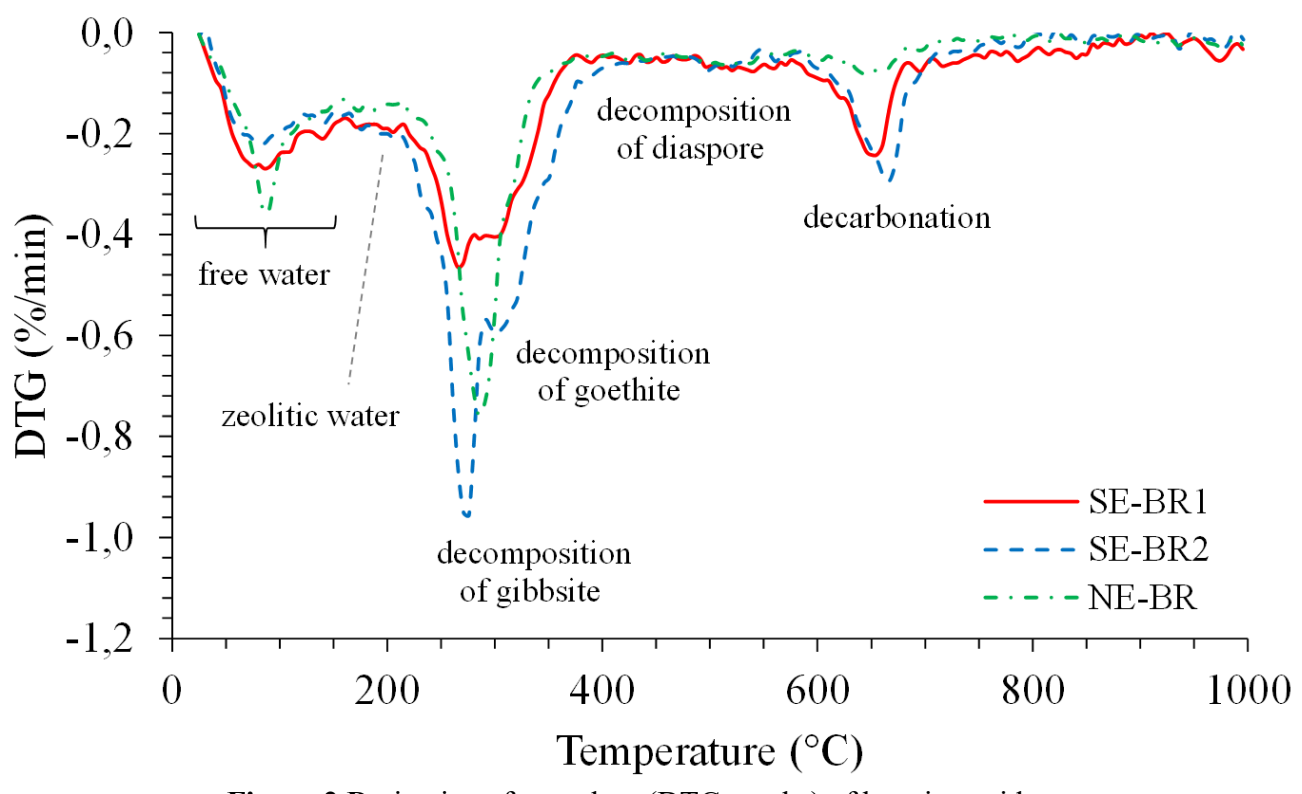

Figure 2 Derivative of mass loss (DTG results) of bauxite residues.

The lower decomposition referred to goethite and gibbsite in the sample SE-BR1 is convergent with the results of chemical analysis when was observed lower amount of iron and aluminum than in the other residues. This information will be relevant for the explanations about the chemical reaction of blended Portland cement with this residue, presented later. In the same way, the calcium content detected by FRX had a direct correlation with the carbonates quantified by thermogravimetric analysis (TGA).

Figure 3 illustrates the particle size distribution of each material and Table 5 presents $d_{10}, d_{50}$, and $d_{90}$, specific surface areas (SSA), and real densities. The high amount of larger particles in NE-BR can explain, in part, the sensible 
displacement of TGA-curve between 210 and $380^{\circ} \mathrm{C}$, difficulting the evaluation of $\mathrm{Al}$ and $\mathrm{Fe}$ phases by thermal analysis due to the overlap of both decomposition phenomena.

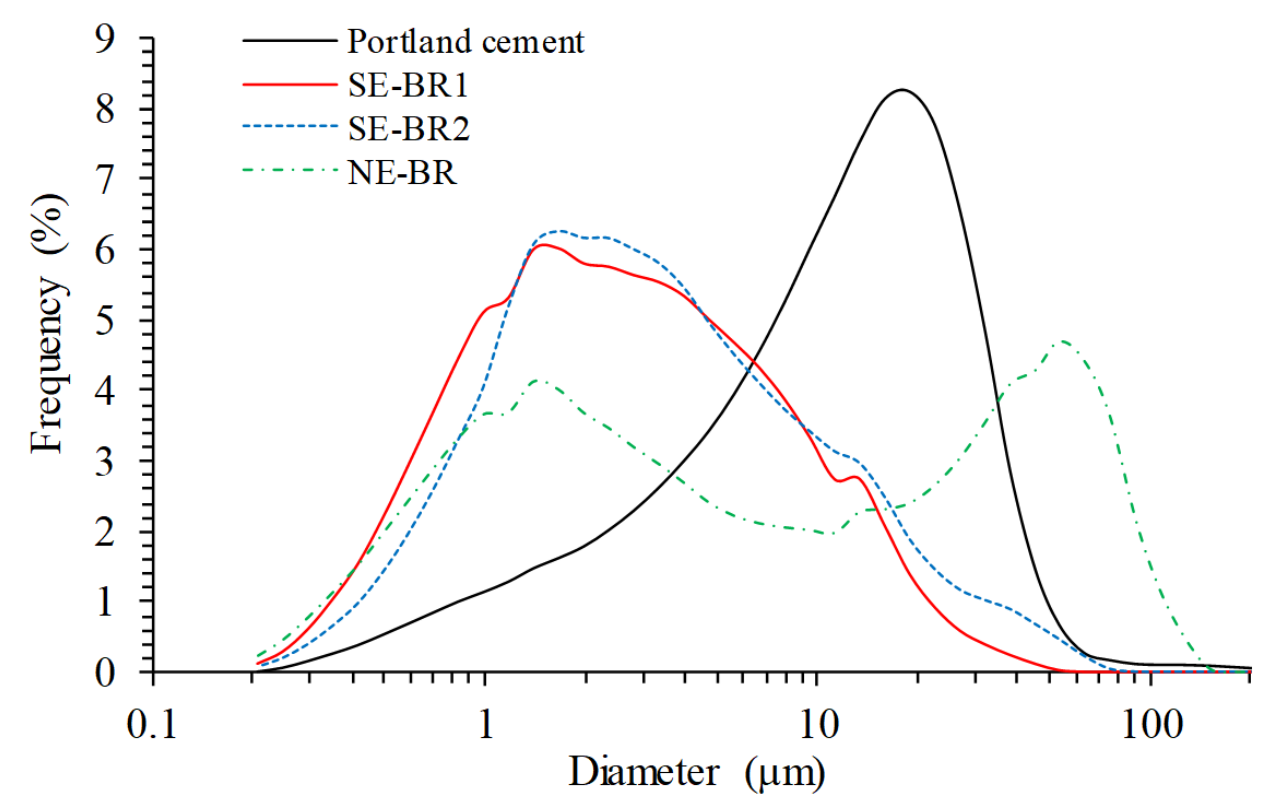

Figure 3 Particle size distribution of cement and bauxite residues.

Table 5 Real densities, specific surface area (SSA), d10, d50, and d90 of each material.

\begin{tabular}{ccccc}
\hline & Portland cement & NE-BR & SE-BR1 & SE-BR2 \\
\hline $\mathrm{d}_{10}(\mathrm{~mm})$ & 5.90 & 0.65 & 0.60 & 0.75 \\
\hline $\mathrm{d}_{50}(\mathrm{~mm})$ & 21.8 & 5.60 & 2.35 & 2.80 \\
\hline $\mathrm{d}_{90}(\mathrm{~mm})$ & 58.3 & 56.0 & 11.0 & 14.0 \\
\hline $\mathrm{SSA}\left(\mathrm{m}^{2} / \mathrm{g}\right), \mathrm{BET}$ & 1.29 & 8.85 & 16.6 & 13.5 \\
\hline Real Density $\left(\mathrm{g} / \mathrm{cm}^{3}\right)$ & 3.10 & 3.28 & 2.96 & 2.98 \\
\hline
\end{tabular}

Samples of SE-BR present similar particle size extension and real density, but the sample NE-BR has coarse particles and higher density, probably in function of the large amount of iron, difficulting the ground. The SSA of three residues is at least 8 times higher than Portland cement, which affects directly the chemical reaction and development of microstructure during the hardening step: the higher the SSA, the higher the water demand to moisten the particles and start the flow.

A common doubt about the characteristics of bauxite residue is its potential to be considered as a pozzolan. Pozzolans are materials consisting of silica and alumina which, in the presence of water, combine with calcium hydroxide resulting in water-stable compounds with binding properties. However, the three BR evaluated in this work did not present pozzolanic activity according to the requisites of Brazilian standard, i.e. the $\mathrm{Ca}(\mathrm{OH})_{2}$ consumption was lower than $436 \mathrm{mg}$ per grams of each BR.

For illustration, Figures 4 to 6 present the SEM images, highlighting some different particles found in the three bauxite residues, and the energy-dispersive X-ray spectroscopy analysis (EDS) confirming the presence of Fe, Al, $\mathrm{Si}, \mathrm{Ti}$ and $\mathrm{Na}$ as the main elements; it was also observed the presence of $\mathrm{Zr}, \mathrm{Mg}, \mathrm{Mn}, \mathrm{Ca}$ and $\mathrm{K}$ in low proportion. However, the semi-quantitative evaluation is not being presented due to some concerns about the inaccuracy of this method for this purpose. 

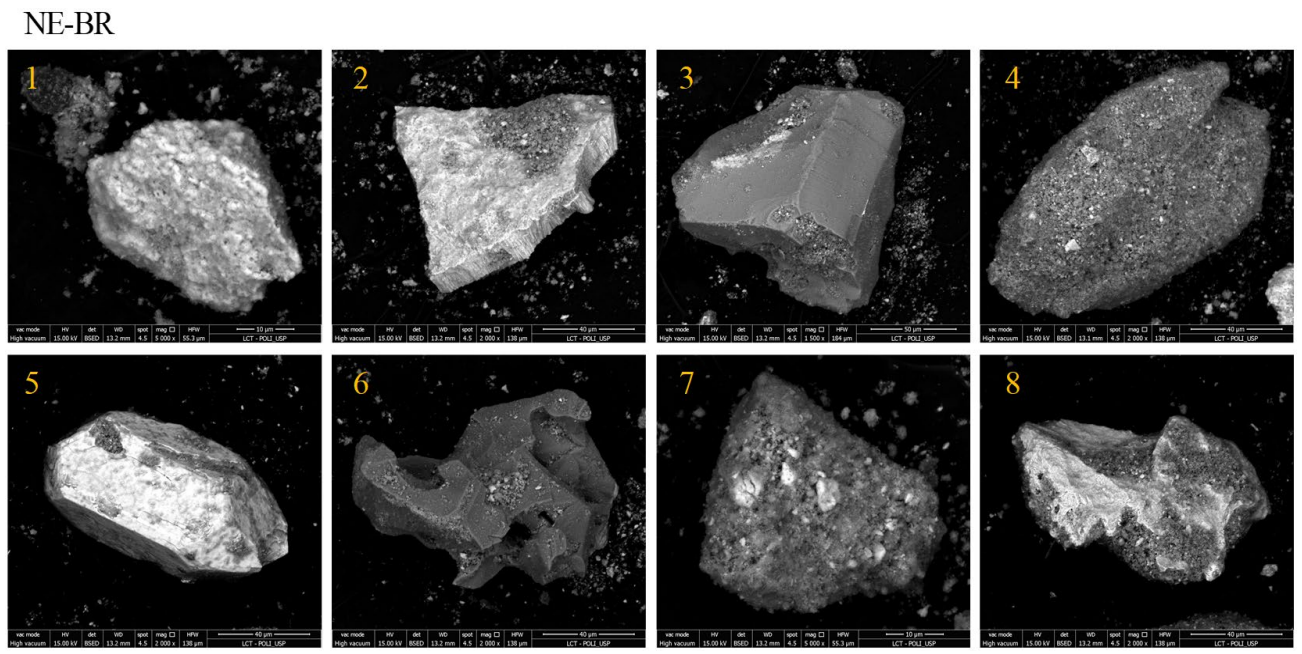

Figure 4 SEM images of NE-BR. EDS illustrates the presence of: 1 - Fe, Al, Si; 2 - Fe; 3 - Ca, Si, Al, Mg; 4 and 7 - Fe, Al, Si, Na, $\mathrm{Ti} ; 5$ - Zr, Si, Al, Fe, Na; 6 - Si; 8 - Al, Si, Na
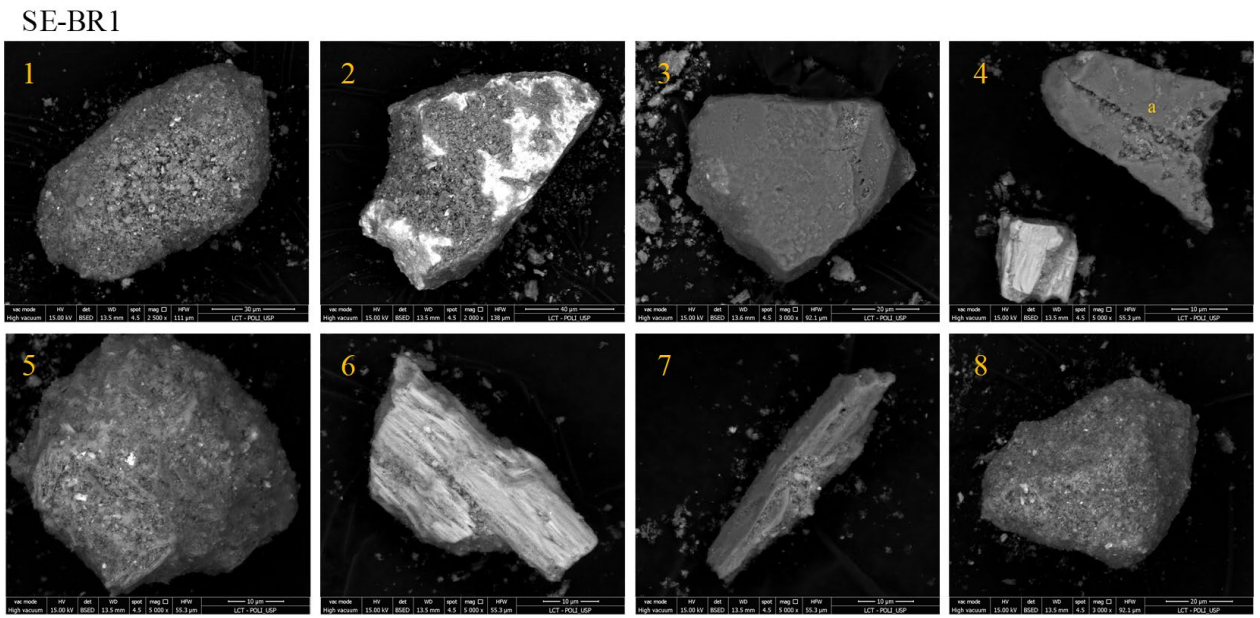

Figure 5. SEM images of SE-BR1. EDS illustrates the presence of: 1 and 8 - Al, Si, Na; $2-\mathrm{Zr}, \mathrm{Si}, \mathrm{Fe} ; 3-\mathrm{Si} ; 4 \mathrm{a}-\mathrm{Si} ; 5-\mathrm{Al}, \mathrm{Si}$, $\mathrm{Fe}, \mathrm{Na} ; 6-\mathrm{Fe}, \mathrm{Al}, \mathrm{Na}, \mathrm{Ti} ; 7-\mathrm{Al}, \mathrm{Si}, \mathrm{K}$.
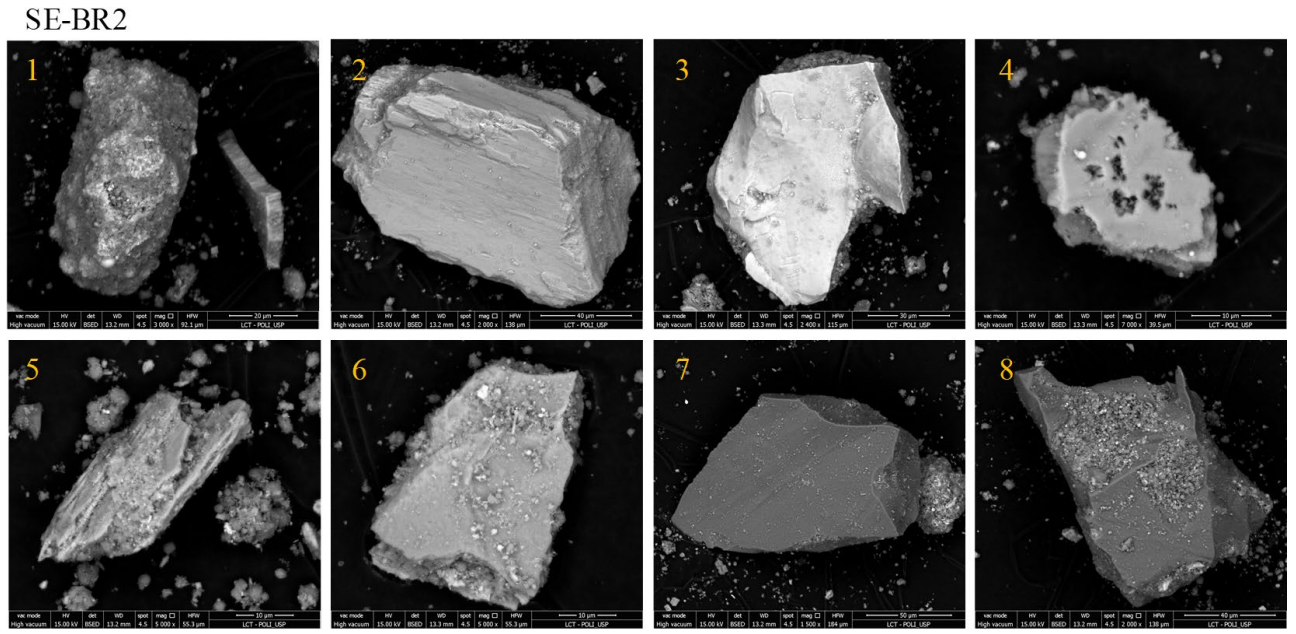

Figure 6. SEM images of SE-BR2. EDS illustrates the presence of: 1 - Al; Fe; $\mathrm{Si}$, Na, Ti; 2 - Al; Fe; 3. Ti, Fe, Mn; 4 - Al, Fe; 5 $\mathrm{Al}, \mathrm{Fe}, \mathrm{Si}, \mathrm{Na} ; 6-\mathrm{Al}, \mathrm{Fe} ; 7$ and $8-\mathrm{Si}$. 


\section{Monitoring the hardening stage of pastes}

\section{Cement hydration reaction}

Figure 7 shows the heat flow released during the hydration of CPV blended with different BR content: (a) NE-BR, (b) SE-BR1, and (c) SE-BR2. The heat released was normalized according to cement content. Even with the changes promoted using different BRs up to $24 \mathrm{~h}$ of monitoring, in this work the main goal was evaluating the very early age of development of microstructure combining the results of chemical reaction and rheometry. So, the cumulative heat during the first 5 hours is illustrated on the right in Figure 7, showing the chemical contribution to the hardening process, at a very early age of cement hydration reaction. In this stage, all compositions with BR presented a delay of heat released, but it was more intense using the SE-BR1.

It is worth to be mention that the wetting period was excluded from this illustration due to the inaccuracy of the method applied in this work and the combined evaluations presented later (rheology vs calorimetry) will be performed using these data.
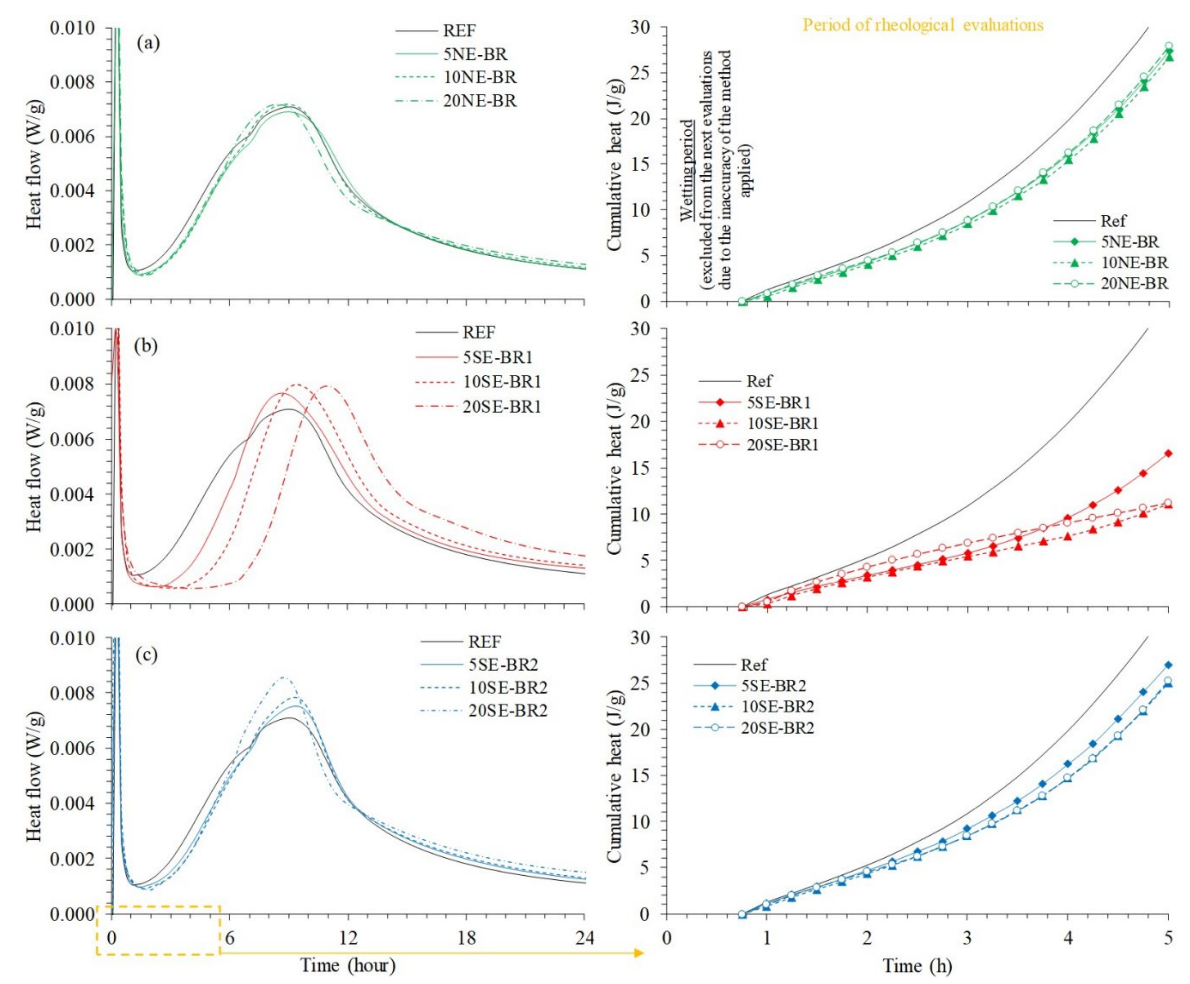

Figure 7 Heat flow released during the hydration reaction of Portland cement blended with different BR types and content. In (a) is presented the results for NE-BR, in (b) for SE-BR1, and (c) SE-BR2. On the right are presented the cumulative heat up to 5 hours of evaluation, the period of rheological evaluations. It was excluded the heat released during the wetting period due to the inaccuracy of the method applied in this work for this period.

The use of mineral additions affects the dilution of clinker phases and the nucleation [11], [12], so changes on the heat released represents the impact of different kind and content of bauxite residue addition.

The use of bauxite residue in association with Portland cement makes the hydration reaction increasingly complex: the presence of soluble aluminates in contact with $\mathrm{Ca}^{2+}$-ions from Portland cement, produces calcium aluminates, and it can accentuate or cause a delay in the hydration reaction, depending on the concentration of dissociated aluminates from bauxite residue [19], [24], [30]-[38]. Because of this, it was not observed in this work, a tendency in the function of the kind and content of bauxite residue [12], [39]-[41].

There is a consensus in the literature that the presence of aluminates, in excess, causes a delay in the nucleation of C-S-H, because the precipitated containing Al-ions does not work as a nucleation seed [24], [42]. Additionally, during 
the AFt formation, the Al-ions are quickly consumed, due to the dissolution of alkaline sulfates of cement. There also is an inhibitory effect, even at lower concentrations, which can affect the dissolution during the early hydration of $\mathrm{C}_{3} \mathrm{~S}$.

Converging with what was reported by Nicoleau et al. [41] using other materials, the kind and content of bauxite residue used replacing the Portland cement influenced considerably the formation of Si-O-Al bonds, affecting the induction period.

In the same way, there is no convergence about the $\mathrm{Na}^{+}$-ion solubilized from the bauxite residues used in this work: it was observed the most impacting delay in the chemical reaction of compositions blended with SE-BR1, but it was quantified an intermediary value comparing with the other BRs.

Changes in the induction period were higher using the substitution by SE-BR1. Scrivener et al. [43] using the geochemical theory of dissolution, suggest the growing of disorganized C-S-H on the original grains and finishing the induction stage even at $\mathrm{Ca}^{2+}$ undersaturation.

Applying the concept presented by Romano et al. [12] the monitoring of heat flow in the acceleration period showed that the nucleation effect of powder was negligible using NE-BR, due to a large amount of coarse particles, but considerable in the compositions with SE-BR1 and SE-BR2. During this period there is a dynamic equilibrium, and removing the ions from the solution by precipitation of hydrated compounds, the under-saturation of alite will increase, causing an increase in the dissolution rate up to the replacement of ions in solution [12]. In this way, using different kinds and contents of bauxite residue, it was observed distinct dissolution rates.

During the deceleration stage, there is a considerable decrease in the available surface for the growth of hydrated products, so they start to impinge. In this way, the calcium silicate hydrate formation and portlandite are occurring slowly [12]. At that stage, the presence of the larger amount of aluminates inserted using bauxite residue affects the formation of ettringite (AFt) and conversion in monosulfoaluminate (AFm) [24].

\section{Gain on consistency over time}

Figure 8 represents the impact of using bauxite residue collected from the different sites in Brazil in the gain on consistency over the time (G') of blended Portland cement.

The storage modulus, G', express the elastic response of material during the transition from fluid to elastic behavior in the consolidation. At the oscillatory test, part of the applied strain (at a controlled frequency) is dissipated by the energy dissipation mechanisms in the bulk of cement paste, and another part is stored in the material: higher G' denotes more solid-like property. So, during the time sweep test, G' was monitored under a quasi-static condition, indicating the development of the suspension stiffening when at rest and that can be related to the applied or molded material.

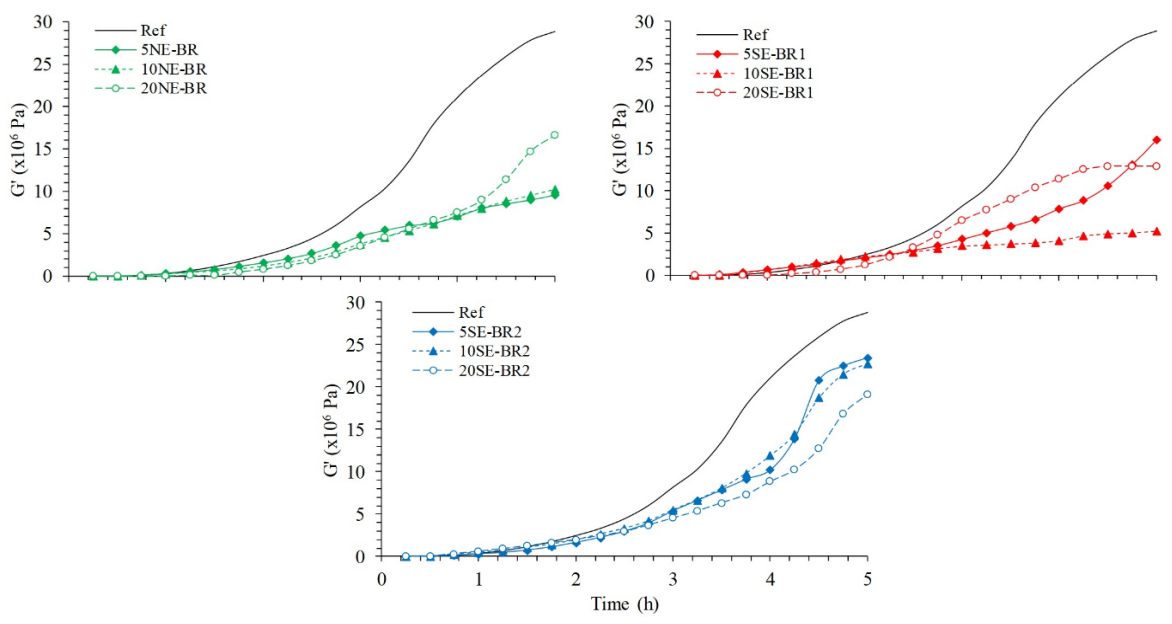

Figure 8 Gain on the consistency of blended pastes. From top to bottom are presented the results for NE-BR, SE-BR1, and SEBR2, respectively.

For the compositions with NE-BR the impact of residue content is negligible up to 4 hours of monitoring, and after this time only in the composition with the highest amount of BR presented an accentuated growth in G', showing the increase in the particle agglomeration. 
For the other compositions, a similar behavior was observed up to 2.5 hours of monitoring, independently of kind of bauxite residue. However, after this time, the gain on consistency promoted by the SE-BR2 was more accentuated than by the SE-BR1 and close to the reference paste.

These alterations in viscoelastic behavior were irreversible due to the hydration reactions of the cement. Thus, an understanding of the chemical influence related to this stage of fluid-to-solid transition is important for the comprehension of how those changes occurred.

\section{Combined evaluation: $G^{\prime}$ vs cumulative heat}

A combined evaluation of the results obtained in the different tests can provide a clearer notion of the cause-effect relationship in the hardening process of the cementitious suspensions evaluated as a function of the type and content of bauxite residue. It was possible to visualize that the kinetics of agglomeration and the kinetics of chemical reactions are phenomena that occur in parallel and are directly related.

Figure 9 shows the physicochemical contribution to the hardening stage of each suspension. In (a) is presented the results for NE-BR, in (b) for SE-BR1, and (c) SE-BR2.
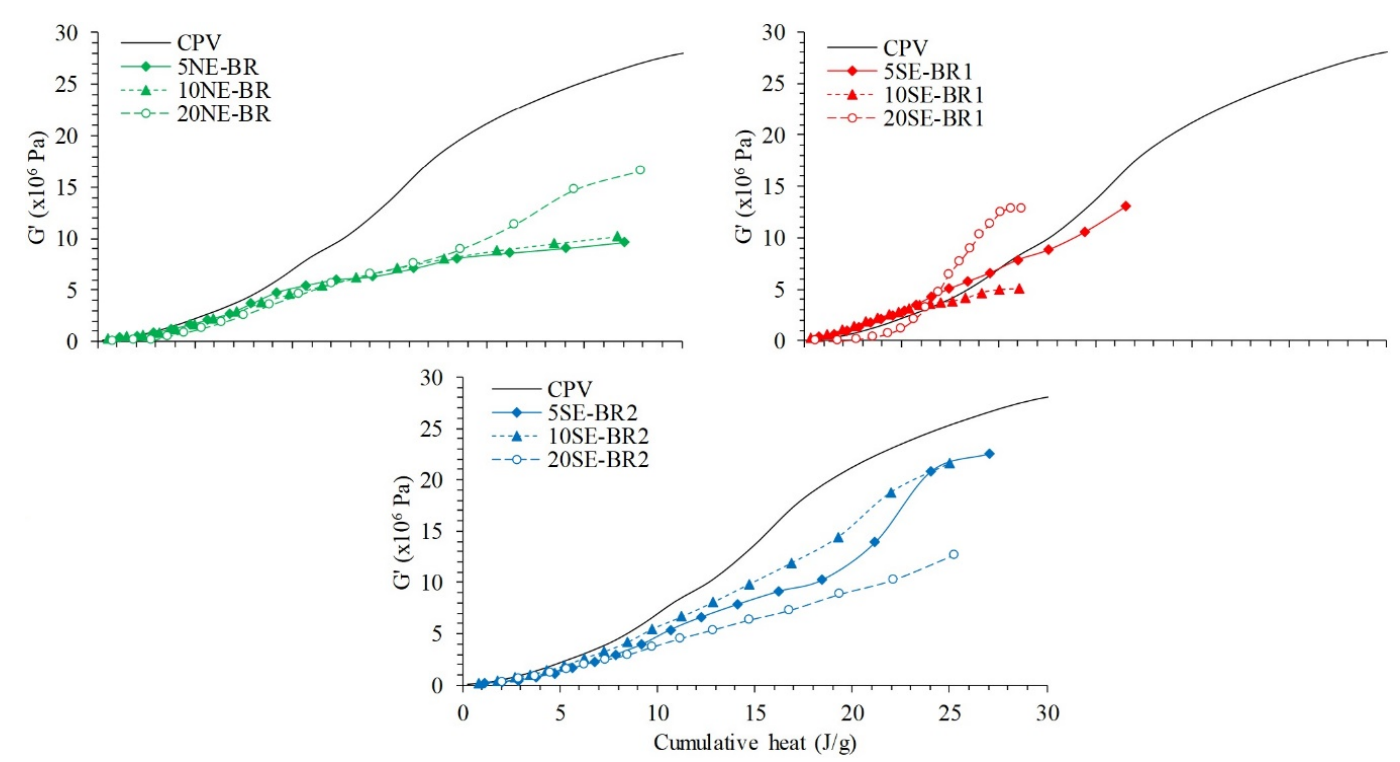

Figure 9 Monitoring the hardening stage combining the results of oscillatory rheometry and isothermal calorimetry. In above is presented the results for NE-BR, in the middle for SE-BR1 and below for SE-BR2.

In summary, using bauxite residues of these three distinct sites, different developments of microstructure were observed. In the compositions with NE-BR, the use of residue had a negligible influence on the cement hydration and on the gain on consistency over time. The only difference was observed in the composition 20NE-BR after 4 hours of monitoring the G'. On the other hand, the most impacting influence of the SE-BR1 was in the chemical reaction, causing a considerable delay for the development of hydrated compounds, but the gain on consistency was also affected by the content of residue. In the compositions with partial replacement of Portland cement by 5 and $10 \%$ of SE-BR1, the hardening stage followed the same pattern of physicochemical changes that were observed for the reference paste at least up to 2 hours of monitoring. However, for the composition SE-20BR1, the changes in G' value were very slow at the beginning of hardening, but from 2.5 hours of monitoring the physical contribution had more impact on the development of microstructure.

This is an important observation because in this composition was quantified the highest delay in the chemical reaction, confirming that the discussion of the hardening process must be done correlating both parameters.

This behavior reveals an abrupt rise in the dominance of the agglomeration forces due to the cement hydration evolution, thus indicating the minimum amount reaction requested to change the balance to surface attractive forces in the system. More specifically, the ionic strength and the particle specific surface area are increased due to the formation of cement hydrated compounds, thus increasing these agglomeration forces. 
Finally, even with the clear impact of using SE-BR2 (kind and content) during the development of the hardening stage, the difference with the reference paste was the lowest compared with the other residues.

\section{CONCLUSION}

The proper replacement of Portland cement by bauxite residue depends, as in the case of other mineral additions, on the correct evaluation of the resulting rheological properties after the addition. These properties depend on the different physical characteristics of the particles concerning the cement.

Converging with some studies reported in the literature, it can be said that in this work, the hardening stage of the cementitious material was not only related to the chemical reaction, but also to the surface forces raised with the hydration reaction and with the changes in the liquid phase: even with the impact of bauxite residue, the chemical reaction was fundamental but insufficient for the gain on the consistency of the suspensions.

The Brazilian Northeast residue (NE-BR) was the only one that presented a negligible impact on the Portland cement chemical reaction (up to $10 \%$ of substitution), independently of the content used. However, the microstructural hardening was lower than for the reference suspension (prepared using only Portland cement).

For the other suspensions, even with the lower rigidification comparing with the Portland cement, the changes promoted using different contents of bauxite residue were negligible up to 2.5 hours of monitoring: although after this time, the differences of $\mathrm{G}^{\prime}$ over time were more intense in the compositions with SE-BR1.

On the other hand, both residues from the Brazilian Southeast have had an impact on the development of the chemical reaction of cement: causing a delay due to the presence of a high amount of soluble sodium and aluminates (SE-BR1) or accentuate the nucleation effect (SE-BR2).

So, the correct comprehension of the phenomena that occur during the hardening of cementitious materials, i.e. from viscous fluid to elastic solid behavior, is extremely important for the development of eco-friendly cement composition, with better and more durable properties.

The analysis of the changes occurred during the hardening is not insignificant since several physicochemical phenomena take place at the same time and always change the cement microstructure. This means that for studies with other types of cement associated with other kinds of content of bauxite residue the trends could not be the same as those observed in this work.

\section{ACKNOWLEDGMENTS}

The authors wish to thank the Alcoa Foundation, the Brazilian Aluminium Company, the Fundação de Amparo à Pesquisa do Estado de São Paulo (Research Grant 2012/19262-2) and the Conselho Nacional de Desenvolvimento Científico e Tecnológico (Research Grant - 155357/2016-6) for the support during the development of this research.

\section{REFERENCES}

[1] S. Xue et al., "Industrial wastes applications for alkalinity regulation in bauxite residue: a comprehensive review," J. Cent. South Univ., vol. 26, no. 2, pp. 268-288, 2019.

[2] D. J. Cooling, P. S. Hay, and L. Guilfoyle, "Carbonation of bauxite residue," in Proc. 6th Int. Alumina Qual. Workshop, Brisbane, 2002, pp. 185-190.

[3] Y. Pontikes, P. Nikolopoulos, and G. N. Angelopoulos, "Thermal behaviour of clay mixtures with bauxite residue for the production of heavy-clay ceramics," J. Eur. Ceram. Soc., vol. 27, no. 2-3, pp. 1645-1649, 2007., http://dx.doi.org/10.1016/j.jeurceramsoc.2006.05.067.

[4] M. Gräfe, G. Power, and C. Klauber, "Bauxite residue issues: III. Alkalinity and associated chemistry," Hydrometallurgy, vol. 108, no. 1-2, pp. 60-79, 2011

[5] C. Klauber, M. Gräfe, and G. Power, "Bauxite residue issues: II. options for residue utilization," Hydrometallurgy, vol. 108, no. 1-2, pp. 11-32, 2011., http://dx.doi.org/10.1016/j.hydromet.2011.02.007.

[6] R. C. O. Romano, Avaliação das Interações Físico-Químicas entre Resíduo de Bauxita e Cimento Portland. São Paulo: Universidade de São Paulo, 2016.

[7] L. Arnout, T. Hertel, M. Liard, D. Lootens, and Y. Pontikes, "Use of bauxite residue slurry as single activator in a hybrid binder system," in Proc. 35th Conf. Exhib. ICSOBA - Bauxite Alumina Alum. Ind. Eur. New Glob. Dev., ICSOBA, Hamburg, 2017, pp. 519528.

[8] R. C. O. Romano, H. M. Bernardo, D. A. Niza, J. A. F. S. Mesquita, M. A. Cincotto, and R. G. Pileggi, Evaluation of the Hardened State Properties of Zero-Cement Mortars Produced Using Bauxite Residue as an Activator to Ground Blast Furnace Slag. Athens: An Serbruyns, 2018, pp. 293-300. 
[9] A. L. Fujii, D. dos Reis Torres, R. C. de Oliveira Romano, M. A. Cincotto, and R. G. Pileggi, "Impact of superplasticizer on the hardening of slag Portland cement blended with red mud," Constr. Build. Mater., vol. 101, pp. 432-439, 2015. , http://dx.doi.org/10.1016/j.conbuildmat.2015.10.057.

[10] C. C. Liberato, R. C. O. Romano, M. Montini, J. B. Gallo, D. Gouvea, and R. G. Pileggi, "Efeito da calcinação do resíduo de bauxita nas características reológicas e no estado endurecido de suspensões com cimento Portland," CEP, vol. 5424, pp. 970, 2013.

[11] R. C. O. Romano, C. C. Liberato, M. Montini, J. B. Gallo, M. A. Cincotto, and R. G. Pileggi, "Evaluation of transition from fluid to elastic solid of cementitious pastes with bauxite residue using oscillation rheometry and isothermal calorimetry," Appl. Rheol., vol. 23, pp. 9, 2013.

[12] R. C. O. Romano, H. M. Bernardo, M. H. Maciel, R. G. Pileggi, and M. A. Cincotto, "Using isothermal calorimetry, X-ray diffraction, thermogravimetry and FTIR to monitor the hydration reaction of Portland cements associated with red mud as a supplementary material," J. Therm. Anal. Calorim., vol. 137, no. 6, pp. 1877-1890, 2019, http://dx.doi.org/10.1007/s10973-01908095- $\mathrm{x}$.

[13] A. L. Fujii, D. R. Torres, R. C. O. Romano, M. A. Cincotto, and R. G. Pileggi, "Impact of superplasticizer on the hardening of slag Portland cement blended with red mud," Constr. Build. Mater., vol. 101, pp. 432-439, 2015.

[14] D. Dodoo-Arhin, R. A. Nuamah, B. Agyei-Tuffour, D. O. Obada, and A. Yaya, "Awaso bauxite red mud-cement based composites: characterisation for pavement applications," Case Stud. Constr. Mater., vol. 7, pp. 45-55, 2017.

[15] P. Krivenko et al., "Development of alkali activated cements and concrete mixture design with high volumes of red mud," Constr. Build. Mater., vol. 151, pp. 819-826, 2017.

[16] R. C. O. Romano et al., "Impact of using bauxite residue in microconcrete and comparison with other kind of supplementary cementitious material," in Proc. 35th Conf. Exhib. ICSOBA, Hamburg, 2017, pp. 505-518.

[17] Y. Pontikes and G. N. Angelopoulos, "Bauxite residue in cement and cementitious applications: current status and a possible way forward," Resour. Conserv. Recycling, vol. 73, pp. 53-63, 2013.

[18] J. Roth and J. Falter, "Potential commercial processes for the utilization of bauxite residues," in Proc. 35th Conf. Exhib. ICSOBA Bauxite Alumina Alum. Ind. Eur. New Glob. Dev., ICSOBA, Hamburg, 2017, pp. 539-546.

[19] M. Singh, S. N. Upadhayay, and P. M. Prasad, "Preparation of special cements from red mud," Waste Manag., vol. 16, no. 8, pp. $665-670,1996$.

[20] M. G. Sujana, R. S. Thakur, B. C. Acharya, S. N. Das, and S. B. Rao, Effect of Calcination and Physico-Chemical Properties of Red Mud. Washington: U.S. Department of Energy, 1996. [Online]. Available: https://www.osti.gov/biblio/371938

[21] K. Evans, "The history, challenges, and new developments in the management and use of bauxite residue," J. Sustain. Metall., vol. 2, no. 4, pp. 316-331, 2016.

[22] M. S. Garcia, "Modificação do resíduo de bauxita gerado no processo Bayer por tratamento térmico," M.S. thesis, Univ. São Paulo, São Paulo, 2012.

[23] Associação Brasileira de Normas Técnicas, Cimento Portland-Requisitos, ABNT NBR 16697, 2018.

[24] R. C. O. Romano, H. M. Bernardo, M. H. Maciel, R. G. Pileggi, and M. A. Cincotto, "Hydration of Portland cement with red mud as mineral addition," J. Therm. Anal. Calorim., vol. 131, no. 3, pp. 2477-2490, 2018.

[25] R. A. Rojas-Ramírez, M. H. Maciel, R. C. de Oliveira Romano, R. G. Pileggi, and A. C. V. Coelho, "The impact of vermiculite residual fines in the rheological properties of cement pastes formulated with different waste contents," Appl. Clay Sci., vol. 170, pp. 97-105, 2019.

[26] W. Liu, J. Yang, and B. Xiao, "Application of Bayer red mud for iron recovery and building material production from alumosilicate residues," J. Hazard. Mater., vol. 161, no. 1, pp. 474-478, 2009.

[27] X. Wang, T. Sun, S. Wu, C. Chen, J. Kou, and C. Xu, "A novel utilization of Bayer red mud through co-reduction with a limonitic laterite ore to prepare ferronickel," J. Clean. Prod., vol. 216, pp. 33-41, 2019.

[28] A. Mancini et al., "Fe(III) uptake by calcium silicate hydrates," Appl. Geochem., vol. 113, pp. 104460, 2020.

[29] F. M. Kaußen and B. Friedrich, "Phase characterization and thermochemical simulation of (landfilled) bauxite residue ("red mud") in different alkaline processes optimized for aluminum recovery," Hydrometallurgy, vol. 176, pp. 49-61, 2018.

[30] D. P. Bentz, "Modeling the influence of limestone filler on cement hydration using CEMHYD3D," Cement Concr. Compos., vol. 28, no. 2, pp. 124-129, 2006.

[31] K. De Weerdt, M. B. Haha, G. Le Saout, K. O. Kjellsen, H. Justnes, and B. Lothenbach, "Hydration mechanisms of ternary Portland cements containing limestone powder and fly ash," Cement Concr. Res., vol. 41, no. 3, pp. 279-291, 2011.

[32] J. Duchesne and M. A. Be'rube', "Effect of supplementary cementing materials on the composition of cement hydration products," Adv. Cement Base. Mater., vol. 2, no. 2, pp. 43-52, 1995.

[33] R. Snellings, G. Mertens, Ö. Cizer, and J. Elsen, "Early age hydration and pozzolanic reaction in natural zeolite blended cements: Reaction kinetics and products by in situ synchrotron X-ray powder diffraction," Cement Concr. Res., vol. 40, no. 12, pp. 1704-1713, 2010 . 
[34] A. A. Elgalhud, R. K. Dhir, and G. Ghataora, "Limestone addition effects on concrete porosity," Cement Concr. Compos., vol. 72, pp. 222-234, 2016.

[35] A. M. Ramezanianpour and R. D. Hooton, "A study on hydration, compressive strength, and porosity of Portland-limestone cement mixes containing SCMs," Cement Concr. Compos., vol. 51, pp. 1-13, 2014.

[36] R. Kumar and B. Bhattacharjee, "Porosity, pore size distribution and in situ strength of concrete," Cement Concr. Res., vol. 33, no. 1, pp. 155-164, 2003.

[37] P. E. Tsakiridis, S. Agatzini-Leonardou, and P. Oustadakis, "Red mud addition in the raw meal for the production of Portland cement clinker," J. Hazard. Mater., vol. 116, no. 1-2, pp. 103-110, 2004.

[38] J. Zhang, E. A. Weissinger, S. Peethamparan, and G. W. Scherer, "Early hydration and setting of oil well cement," Cement Concr. Res., vol. 40, no. 7, pp. 1023-1033, 2010.

[39] F. Begarin, S. Garrault, A. Nonat, and L. Nicoleau, "Hydration of alite containing aluminium," Adv. Appl. Ceramics, vol. 110, no. 3, pp. 127-130, 2011.

[40] A. Quennoz and K. L. Scrivener, "Interactions between alite and C3A-gypsum hydrations in model cements," Cement Concr. Res., vol. 44, pp. 46-54, 2013.

[41] L. Nicoleau, E. Schreiner, and A. Nonat, "Ion-specific effects influencing the dissolution of tricalcium silicate," Cement Concr. Res., vol. 59, pp. 118-138, 2014.

[42] S. Garrault, A. Nonat, Y. Sallier, and L. Nicoleau “On the Origin of the Dormant Period of Cement Hydration”, in: 13th International Congress on the Chemistry of Cement (ICCC), Madrid, 2015.

[43] K. L. Scrivener, P. Juilland, and P. J. M. Monteiro "Advances in understanding hydration of Portland cement" Cement Concr. Res., vol. 78, pp. 38-56, 2015. https://doi.org/10.1016/j.cemconres.2015.05.025.

Author contributions: RCOR: Study planning, supervision, funding acquisition, evaluation/analysis of the results, paper writing. JAFSM: Development of the practical work, data evaluation, support in the paper writing. HMB: Development of the practical work, data evaluation. DAN: Development of practical work. MHM: Evaluation/analysis of the results, support in the paper writing. MAC: Supervision, discussion of the results, revision of the paper. RGP: Study planning, supervision, funding acquisition, discussion of the results, revision of the paper.

Editors: Fernando Pelisser, José Luiz Antunes de Oliveira e Sousa, Guilherme Aris Parsekian. 